\title{
CD4-blockade can induce protection from peanut-induced anaphylaxis
}

\author{
Joana Duarte ${ }^{1,2}$, Marta Caridade ${ }^{1,2}$ and Luis Graca ${ }^{1,2 *}$ \\ 1 Instituto de Medicina Molecular, University of Lisbon, Lisbon, Portugal \\ 2 Instituto Gulbenkian de Ciência, Oeiras, Portugal
}

\section{Edited by:}

Stephen Paul Cobbold, University of Oxford, UK

\section{Reviewed by:}

Alain Le Moine, Université Libre de Bruxelles, Belgium

Hans-dieter Volk, Charité - University

Medicine Berlin, Germany

Valerie Julia, INSERM, France

*Correspondence:

Luis Graca, Instituto de Medicina Molecular, University of Lisbon,

Avenida Professor Egas Moniz, 1649-025 Lisbon, Portugal.

e-mail: lgraca@fm.ul.pt
Monoclonal antibodies (mAb) have been shown effective in inducing immune tolerance in a range of animal models of autoimmunity, allergy, and transplantation. We investigated whether CD4-blockade, effective in inducing transplantation tolerance, could prevent systemic immune responses leading to anaphylaxis. We found that treatment with a nondepleting anti-CD4 mAb could prevent peanut-induced anaphylaxis following subsequent systemic exposure to crude peanut extract (CPE). Furthermore, the effect of CD4-blockade did not interfere with overall immune competence, as anti-CD4 treated mice remained fully competent to respond to unrelated antigens. Protection from anaphylaxis correlated with increased frequency of Foxp3 $^{+}$regulatory T cells (Treg), and was abrogated following Treg depletion. Taken together our data suggest that activation of T cells by CPE in presence of CD4-blockade leads to Treg expansion that can prevent peanut-induced anaphylaxis.

Keywords: immune tolerance, anaphylaxis, peanut, regulatory T cells, Foxp3, anti-CD4 monoclonal antibody

\section{INTRODUCTION}

Anaphylaxis is an acute, life-threatening, allergic reaction where a physiologic process that normally acts in a local and limited manner to protect against infection occurs massively and systemically. Peanut allergy is a major cause of food-induced anaphylaxis, affecting around $1 \%$ of the population, with increasing prevalence worldwide (Kanny et al., 2001; Sampson, 2004). To date there is no cure for peanut allergy, and unlike many other food allergies, it persists through adulthood. Currently, avoidance is the only treatment advised. There is therefore, a clear need for safe and effective tolerance-inducing therapies for patients who might be exposed to anaphylactic reactions.

Monoclonal antibodies ( $\mathrm{mAb}$ ) that target $\mathrm{T}$ cell co-receptor and co-stimulatory molecules have been reported effective in inducing tolerance to non-self antigens. Waldmann and coworkers have shown non-lytic CD4 antibodies (with an isotype that does not directly deplete target cells) can induce long-term transplantation tolerance in mice (Graca et al., 2003; Kendal and Waldmann, 2010). The resulting tolerance state is mediated by Foxp $3^{+}$regulatory T cells (Treg), although other mechanisms may also operate (Graca et al., 2002, 2004; Lin et al., 2002). It was reported that a non-depleting anti-CD4 $\mathrm{mAb}$ was effective in preventing allergic airways disease in mice sensitized with ovalbumin (OVA; Li et al., 1999a). We have recently extended these data, showing that tolerance can be induced in mice to a clinically relevant aeroallergen - house dust mite (HDM). In this case, tolerant mice were protected from airways hyperreactivity (AHR), eosinophilia, goblet cell hyperplasia, and production of antigen-specific IgG1 and

Abbreviations: AHR, airway hyperreactivity; Alum, aluminum hydroxide; CPE, crude peanut extract; HDM, house dust mite; i.p., intra peritoneal; $\mathrm{mAb}$, monoclonal antibody; OVA, ovalbumin.
IgE (Agua-Doce and Graca, 2011). These data contrasts with the disappointing results from a clinical trial with a depleting antiCD4 mAb (keliximab; Kon et al., 1998). In this trial the depleting nature of the mAb precluded the use of a dose sufficient to achieve effective CD4-blockade, as it led to immune suppression.

Surprisingly, the same non-depleting anti-CD4 mAb we successfully used to induce tolerance to HDM (or OVA) was reported to be less effective when tolerance was induced to systemically delivered human factor VIII in a mouse model of hemophilia (Salooja et al., 2002). Therefore, we decided to explore to which extent CD4-blockade is able to prevent a systemic allergic response: anaphylaxis.

We took advantage of a well established model of peanutinduced anaphylaxis, where the antigen crude peanut extract (CPE) is delivered through i.p. injection, allowing the precise control of the dose and time of exposure (Pons et al., 2004). C3H/HeJ mice have high susceptibility to peanut-induced anaphylaxis, being able to produce high peanut-specific antibody titers. Moreover, upon challenge through the i.p. route, these mice develop manifestations of anaphylactic shock, including a sharp drop of body temperature, which facilitates the quantification of clinical manifestations, and resemble anaphylactic reactions in human subjects (Li et al., 2000; Berin et al., 2006).

We confirmed $\mathrm{C} 3 \mathrm{H} / \mathrm{HeJ}$ mice can be sensitized with $\mathrm{CPE}$, producing high titers of CPE-specific Th2-driven antibodies. We found that $\mathrm{CD} 4$-blockade, during the sensitization, prevented the generation of peanut-specific immunoglobulins, even following subsequent sensitization with CPE-alum, rendering the mice protected from anaphylaxis. The protective effect is abrogated following depletion of Treg cells. Importantly, CD4-blockade does not lead to immune deficiency, as mice remain competent to respond to different antigens. 


\section{MATERIALS AND METHODS}

\section{EXPERIMENTAL ANIMALS}

$\mathrm{C} 3 \mathrm{H} / \mathrm{HeJ}$ mice were bred and maintained under specific pathogenfree facilities. Animals were sex-matched and used at $6-10$ weeks of age. All experiments involving animals were approved by Direccao Geral Veterinaria (approval 018831). Sensitization was achieved by administration of $0.5 \mathrm{mg}$ CPE in $2 \mathrm{mg}$ aluminum hydroxide (alum, Alu-gel-S, Serva, Heidelberg, Germany) i.p. at days 1, 7, and 21. Mice were subsequently challenged with $10 \mathrm{mg}$ CPE in PBS i.p.

\section{CLINICAL ASSESSMENT OF ANAPHYLAXIS}

Mice were assessed during 45 min following CPE challenge. Body temperature was measured at the indicated times with a rectally inserted thermal probe. The clinical score was evaluated as described elsewhere ( $\mathrm{Li}$ et al., 2000): 0 - no manifestations; 1 - Scratching/rubbing around the nose and head; 2 - puffiness around eyes and mouth, reduced activity, diarrhea, pilar erecti; 3 - wheezing, labored respiration, cyanosis around mouth and tail; 4 - no activity after prodding, or tremor and convulsion; 5 - death. Scoring was performed blinded by two independent researchers.

\section{CPE PREPARATION}

Peanut flour was extensive defatted with diethyl ether, and the dried defatted peanut flour was extracted in ice-cold $10 \times$ PBS overnight at $4^{\circ} \mathrm{C}$, centrifuged at $30,000 \mathrm{~g}$ for $60^{\prime}$, and filtersterilized. Protein concentration was measured with the BCA method and aliquots were stored at $-20^{\circ} \mathrm{C}$.

\section{MONOCLONAL ANTIBODIES}

Non-depleting anti-CD4 (YTS177), the isotype control (YKIX302), and anti-CD25 (PC61) mAbs were produced in our laboratory using Integra CL1000 flasks (IBS, Chur, Switzerland), purified by $50 \%$ ammonium sulfate precipitation, dialyzed against PBS, and purity checked by native and SDS gel electrophoresis. The hybridomas were generously provided by Professor Herman Waldmann (Oxford, UK).

\section{IN VITRO CULTURES}

Splenocytes $\left(1 \times 10^{6}\right)$ were cultured for 3 days in 96 well plates, with complete culture medium (RPMI-1640 with Glutamax, supplemented with $10 \% \mathrm{FBS}, 1 \%$ hepes, $1 \%$ penicillin/streptomycin, $1 \%$ sodium pyruvate, $0.1 \% \beta$-mercaptoethanol; Invitrogen), with addition of $20 \mu \mathrm{g}$ OVA or CPE. At day 3, cells were centrifuged and supernatants recovered and kept at $-80^{\circ} \mathrm{C}$ until cytokine quantification.

\section{ELISA}

The serum IgE and CPE- or OVA-specific IgG1 was measured in microtiter plates coated with $50 \mu \mathrm{g} / \mathrm{ml} \mathrm{CPE}$ or OVA. IgE was quantified with an Opteia kit (BD Pharmingen) and IgG1 with a kit from Southern Biotech. Quantification of cytokines in cellculture supernatants was performed using IL-10 and IL-13 kits (Peprotech, London, UK), and IL-5 Opteia kits (BD Pharmingen). All assays were performed according to the manufacturer's instructions.

\section{FLOW CYTOMETRY}

Single cell suspensions were analyzed with the following fluorochrome-labeled mAb: CD3 Percp-Cy5.5 (145-2C11), CD4 PE (GK1.5), CD8 APC-Cy7 (53-6.7), CD25 Pe-Cy7 (PC61.5), and Foxp3 (FJK165; eBiosciences). Samples were run in a FACS Canto and analyzed with FlowJo.

\section{STATISTICAL ANALYSIS}

Statistical significance was determined using the two-tailed nonparametric Mann-Whitney $U$ test and $P$ values $<0.05$ were deemed significant $\left({ }^{*} P<0.05\right.$; ${ }^{* *} P<0.01$; $\left.^{* * *} P<0.001\right)$.

\section{RESULTS}

\section{CPE-INDUCED AN ANAPHYLACTIC RESPONSE IN SENSITIZED C3H/HEJ} MICE

$\mathrm{C} 3 \mathrm{H} / \mathrm{HeJ}$ mice have been widely used as an experimental murine model of allergic diseases, being prone for the development of Th2-like immune responses, namely peanut-induced anaphylaxis (Li et al., 2000; Morafo et al., 2003). We found that upon i.p. sensitization with CPE-alum, an anaphylactic response was observed following challenge with CPE administered i.p. (Figure 1A). Female mice appeared to display greater disease severity, however, both males and females developed clinical manifestations of anaphylaxis, reaching a state where they did not respond to external stimuli (score 4). In addition, these mice displayed a sharp drop in body temperature, during the initial $45^{\prime}$ following challenge with CPE (Figures 1B,C). Serum concentration of Th2driven immunoglobulins, such as IgE and CPE-specific IgG1, were markedly increased in CPE-sensitized mice, compared to nonexposed controls (Figures 1D,E). These data are similar to prior reports (Li et al., 2000; Pons et al., 2004), supporting the use of $\mathrm{C} 3 \mathrm{H} / \mathrm{HeJ}$ mice as an adequate model for the study of anaphylaxis.

\section{NON-DEPLETING ANTI-CD4 mAb PREVENTED CPE-INDUCED ANAPHYLAXIS}

We have recently shown non-depleting anti-CD4 $\mathrm{mAb}$ can prevent allergic airways disease in mice in an antigen-specific way (Agua-Doce and Graca, 2011). To assess if this monoclonal antibody was equally efficient in the prevention of a systemic Th2driven response, we investigated whether anti-CD4 treatment could prevent anaphylaxis in $\mathrm{C} 3 \mathrm{H} / \mathrm{HeJ}$ mice.

We found anti-CD4 treatment at the time of sensitization was effective in preventing the development of anaphylactic manifestations observed during the $45 \mathrm{~min}$ following challenge with $\mathrm{CPE}$ (Figures 2A,B). Anti-CD4 treated mice also maintained their body temperature, unlike control animals where the temperature dropped rapidly (Figure 2C). The production of IgE and CPEspecific IgG1 was also impaired in mice treated with anti-CD4 (Figures 2D,E).

\section{ANTI-CD4 DID NOT PREVENT ANAPHYLAXIS IN PRE-SENSITIZED MICE WITH HIGH IGE}

We next assessed the impact of anti-CD4 treatment in presensitized mice. Note that the exposure to CPE at days 36-58 (Figure 3A), probably due to the use of alum, only induced mild clinical manifestations of disease even in the absence of anti-CD4 


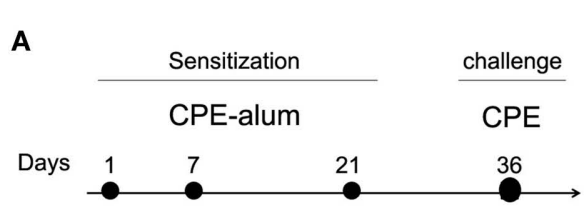

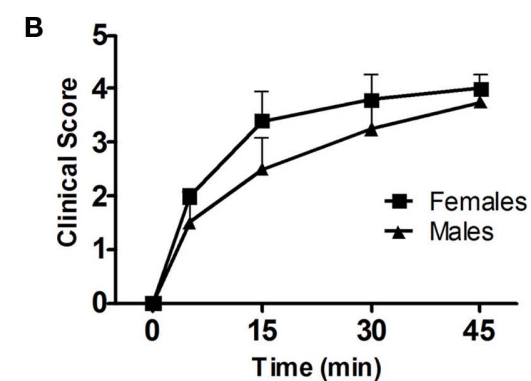

D

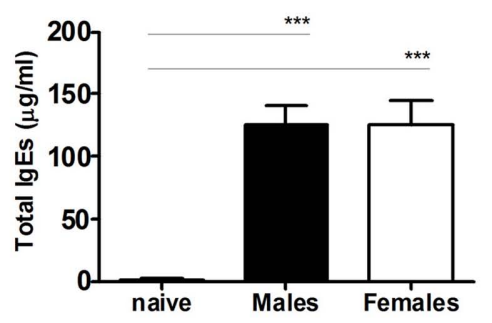

FIGURE 1 | Crude peanut extract induces anaphylaxis in $\mathrm{C} 3 \mathrm{H} / \mathrm{HeJ}$ mice. (A) $\mathrm{C} 3 \mathrm{H} / \mathrm{HeJ}$ mice were sensitized i.p. with $0.5 \mathrm{mg}$ CPE in $2 \mathrm{mg}$ alum on days 1,7 , and 21. The animals were assessed at day 36 following challenge with $10 \mathrm{mg}$ CPE i.p., with clinical score and temperature monitored during $45 \mathrm{~min}$ after challenge. (B) Clinical score was evaluated as described in the Section

"Materials and Methods," and (C) body temperature was measured. Females
C

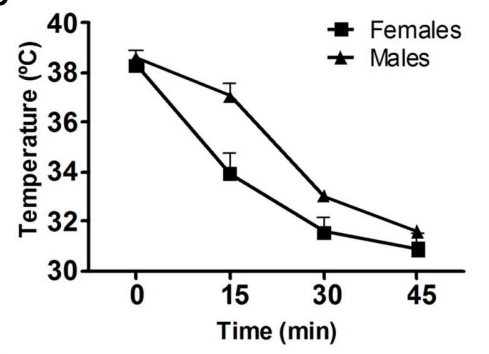

E

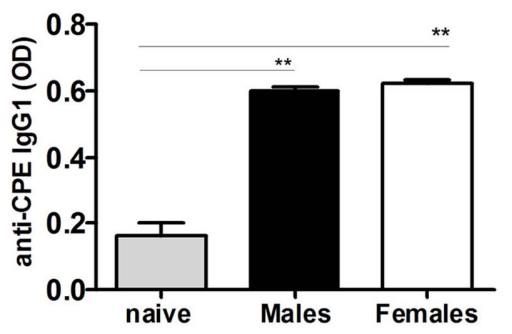

show more severe clinical manifestations of anaphylaxis, compared to male mice, but without reaching statistical significance. (D) Total IgE and (E) CPE-specific IgG1 were measured in the serum of individual mice. Both males and females showed an increase in the immunoglobulin levels compared to naïve mice $\left(n=5,{ }^{*} P<0.01\right)$. Data (B-E) are representative of two independent experiments. (not shown). Furthermore, in spite of such mild clinical manifestations of anaphylaxis, all mice strongly developed anaphylaxis when exposed to CPE without alum at day 73 (Figures 3B,C).

We found that mice sensitized with CPE in advance of antiCD4 treatment were not protected from the development of clinical manifestations of anaphylaxis, namely reduction of body temperature (Figures 3B,C). Mice treated with anti-CD4 had increased levels of total IgE and CPE-specific IgG1, similar to CPE-sensitized controls (Figures 3D,E). These results suggest that in pre-sensitized individuals pre-existing IgE, produced at the time of initial sensitization, will drive clinical manifestations of anaphylaxis in a T-cell independent manner.

\section{NON-DEPLETING ANTI-CD4 MONOCLONAL ANTIBODY-INDUCED PROTECTION FROM SUBSEOUENT EXPOSURE TO CPE}

Non-depleting anti-CD4 mAb was shown to induce long-term tolerance in transplantation (Waldmann and Cobbold, 2001). We also found long-term protection to HDM could be induced with this $\mathrm{mAb}$ in mice (Agua-Doce and Graca, 2011). Therefore, we evaluated whether treatment with non-depleting anti-CD4 at the time of CPE sensitization could protect mice from peanut-induced anaphylaxis following a subsequent sensitization. As a consequence, 2 weeks after treatment, mice were re-sensitized with CPE-alum as shown in Figure 4A. The 2 weeks is sufficient to allow for clearance of the mAb below therapeutic levels, as we found by treating mice with anti-CD4 2 weeks in advance of providing the antigen (in previous experiments using OVA as the antigen, data not shown).

Manifestations of anaphylaxis were evident after challenge in CPE-sensitized mice, whereas mice treated with anti-CD4 were protected from severe clinical manifestations (Figure 4B). In addition, serum titers of IgE and CPE-specific IgG1 remained low in mice treated with anti-CD4 (Figure 4C). Injection of alum alone (in the absence of antigen and anti-CD4) did not prevent subsequent response elicited following sensitization (not shown).

We next compared the production of Th2-type cytokines by $\mathrm{T}$ cells from anti-CD4 treated mice. We cultured spleen T cells for 3 days in presence of CPE stimulation, and quantified the cytokines in cultures supernatants. T cells from mice treated with antiCD4 mAb, unlike splenocytes from control CPE-sensitized mice, did not produce detectable levels of IL-5 and IL-13 (Figure 4D). Several reports have implicated IL-10 in protection from allergy (Akdis et al., 1998, 2004). However, production of IL-10 following in vitro stimulation with CPE was also reduced in cells from anti-CD4 treated mice (Figure 4D). In fact, IL-10 production was higher in cells from animals sensitized with CPE in the absence of anti-CD4 treatment.

Several studies in transplantation have shown that long-term tolerance induced with CD4-blockade is associated with Foxp $3^{+}$ 

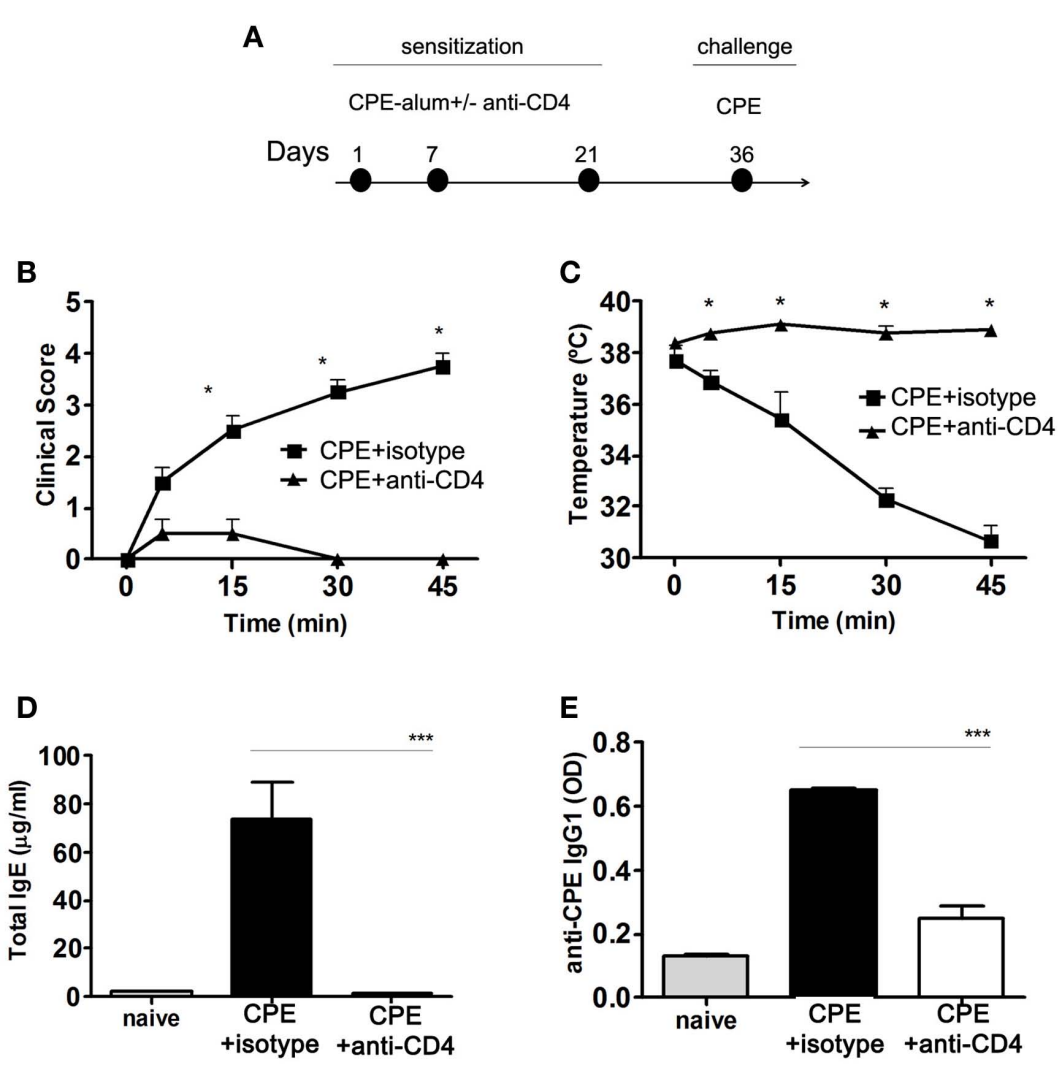

FIGURE 2 | Anti-CD4 prevents peanut-induced anaphylaxis in $\mathrm{C} 3 \mathrm{H} / \mathrm{HeJ}$ mice. (A) Female $\mathrm{C} 3 \mathrm{H} / \mathrm{HeJ}$ mice were sensitized to $\mathrm{CPE}$ at the indicated days, with a group of animals being treated with $1 \mathrm{mg}$ anti-CD4 or an isotype control i.p. at the time of each sensitization. All mice were assessed at day 36 following challenge with $10 \mathrm{mg}$ CPE i.p. (B) Mice were assessed for their clinical score and $(\mathbf{C})$ body temperature during 45 min following CPE challenge. Anti-CD4 treated mice did not develop any significant

manifestations of disease $\left(n=4,{ }^{*} P<0.05\right)$. In addition, CPE-sensitized mice showed a sharp drop of body temperature $\left(n=4,{ }^{*} P<0.05\right)$. (D) Serum concentration of total $\lg E$ and (E) CPE-specific IgG1. Anti-CD4 treated mice maintained lgE levels at a concentration similar to naïve non-immunized mice, while mice treated with an isotype control significantly increased serum lgE and $\operatorname{lgG} 1(n=8, * * * P<0.001)$. Data (B-E) are representative of three independent experiments.

Treg expansion (Cobbold et al., 2004; Graca et al., 2005; Oliveira et al., 2011). We found that although the anti-CD4 mAb has a non-depleting isotype, and does not directly lyse $\mathrm{CD} 4^{+} \mathrm{T}$ cells (Figure A1 in Appendix), the absolute number of $\mathrm{CD}^{+}{ }^{+} \mathrm{T}$ cells in the spleen of anti-CD4 treated mice were lower than in controls (Figure 4E). However, the frequency of Foxp $3^{+}$Treg cells within the $\mathrm{T}$ cell population was significantly increased in anti-CD4 treated mice (Figure 4E).

To further confirm the participation of Treg cells in the protection induced following anti-CD4 treatment, we evaluated the efficacy of CD4-blockade in CD25-depleted mice. We found that mice depleted of CD25 T cells at the time of CD4blockade were not protected from peanut-induced anaphylaxis, induced following subsequent immunization with CPE-alum as described in Figure 4A. In fact, CD25-depleted mice exhibited high levels of total IgE, similar to what was observed in mice not treated with anti-CD4 (Figure 4F). These data suggest Foxp $3^{+}$Treg cells participate in protection from peanutinduced anaphylaxis induced following CD4-blockade. In addition, we compared the effect of CD25 depletion when applied before or after tolerance induction with anti-CD4. We found that treatment with anti-CD25 in advance of tolerance induction was not as effective in abrogating tolerance induction as when CD25 depletion was performed after anti-CD4 treatment (Figure 4G). These data suggest the participation of adaptive Treg cells, induced at the time of anti-CD4 treatment, in tolerance induction.

\section{ANTI-CD4 TREATMENT INDUCED ANTIGEN-SPECIFIC PROTECTION}

We finally assessed whether anti-CD4 treatment was affecting the global immunocompetence, by studying the ability of mAb-treated mice to respond to different antigens. Therefore, following treatment of $\mathrm{C} 3 \mathrm{H} / \mathrm{HeJ}$ mice with $\mathrm{CPE}$ in presence of anti-CD4, some mice were re-sensitized with the same (CPE) or a different (OVA) antigen (Figure 5A). Mice treated with anti-CD4 remained fully competent to respond to sensitization with OVA-alum, developing a Th2-immune response leading to production of high IgE titers (Figure 5B). In fact, the levels of IgE were comparable to what was observed in CPE-sensitized control mice.

Conversely, when we treated mice with anti-CD4 together with OVA, we prevented production of IgE following subsequent sensitization with OVA (Figure 5C). 

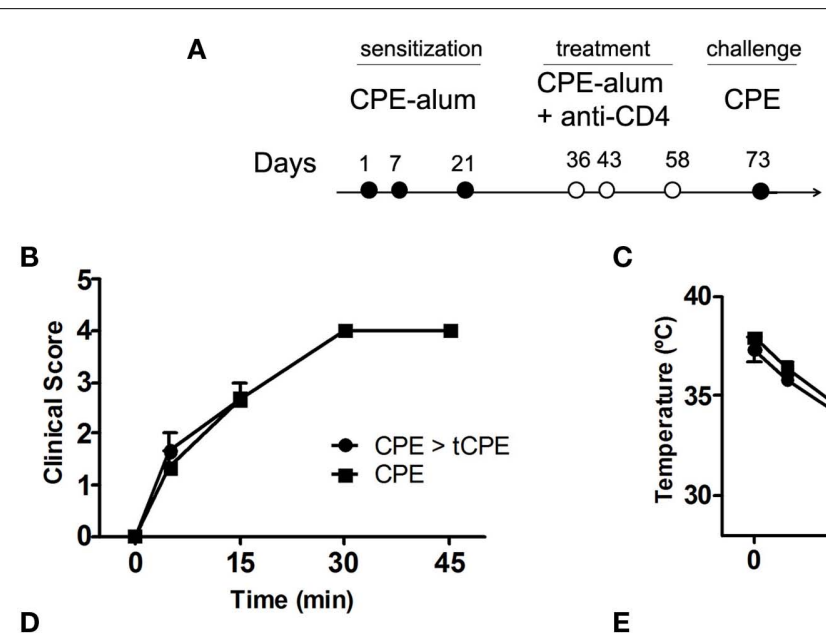

C

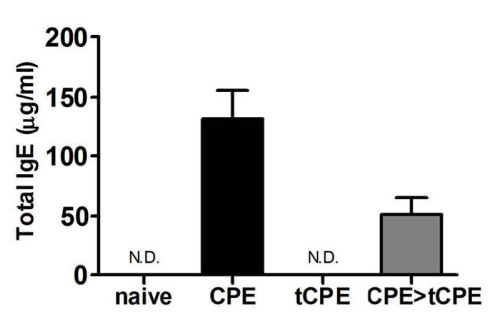

E
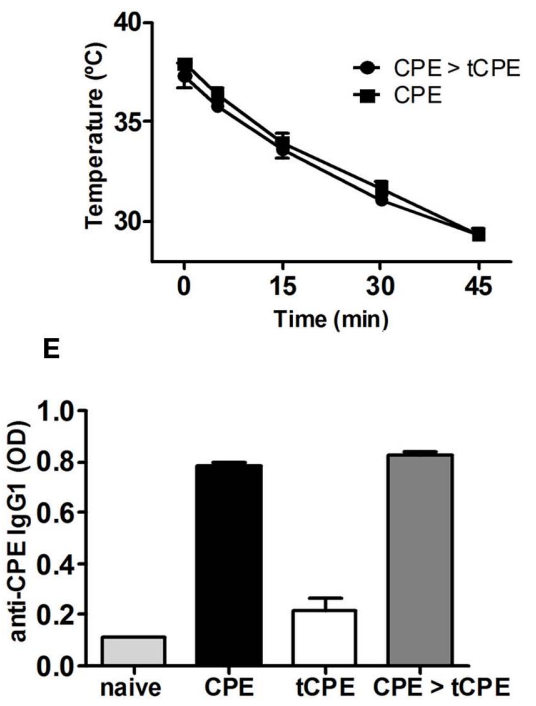

FIGURE 3 | Anti-CD4 does not prevent anaphylaxis in pre-sensitized mice with high titers of IgE. (A) $\mathrm{C} 3 \mathrm{H} / \mathrm{HeJ}$ mice were sensitized with CPE-alum on days 1, 7, and 21, and treated with anti-CD4 administered together with CPE at the indicated days. All mice were assessed at day 73 after challenge with $10 \mathrm{mg}$ CPE i.p.

well as (C) sharp reduction of body temperature. (D) Total IgE and (E) CPE-specific IgG1 levels were similar in sensitized mice even when treated with anti-CD4 after sensitization (CPE and CPE > tCPE). These high levels of immunoglobulins contrast with mice treated with anti-CD4 at the time of initial sensitization (tCPE) that maintain low titers of $\lg E$ and $\lg \mathrm{G} 1$ $(n=4, * * * P<0.001)$. Data (B-E) are representative of two independent experiments.

Taken together these data show anti-CD4 treatment induces unresponsiveness to the antigens administered at the time of CD4-blockade, without preventing subsequent immune responses to different antigens. Therefore, anti-CD4 treated mice remain immune competent.

\section{DISCUSSION}

Our data show CD4-blockade is effective in inducing antigenspecific tolerance to $\mathrm{CPE}$, thus preventing subsequent sensitization with the same antigens. This conclusion contrasts with the apparent difficulty to induce tolerance in mice to systemically delivered human factor VIII or factor IX using the same mAb (Salooja et al., 2002). We are currently investigating the mechanisms that may explain the reason distinct proteins are tolerated with different ability.

Anti-CD4 is a non-depleting monoclonal antibody which has been extensively studied in several animal models of immune pathology. In transplantation and autoimmune arthritis, nondepleting anti-CD4 is effective in preventing transplant rejection and inducing long-term tolerance in mice (Waldmann and Cobbold, 2001; Duarte et al., 2010). Experiments with TCR-transgenic mice have shown the tolerant state is maintained by Foxp $3^{+}$ Treg cells that can be induced from Foxp $3^{-}$precursors (Cobbold et al., 2004; Oliveira et al., 2011). Such T cells can actively maintain tolerance by recruiting non-tolerant cells into the regulatory pool - a phenomenon termed infectious tolerance (Qin et al., 1993; Graca et al., 2000; Waldmann et al., 2006). In fact, mice transplanted under the cover of non-depleting anti-CD4 $\mathrm{mAb}$ do not become tolerant (i.e., they reject the transplant) when treated with anti-CD25 (Cobbold et al., 2006). We followed the same approach to show mice treated with anti-CD25 remained competent to produce $\mathrm{CPE}$-specific antibodies, suggesting a similar mechanism of action. We cannot exclude that part of the effect of CD4-blockade is due to activation-induced cell death of $\mathrm{T}$ cells specific for the antigen present at the time of tolerance induction - a mechanism well described in transplantation tolerance induced with co-stimulation blockade ( $\mathrm{Li}$ et al., 1999b; Wells et al., 1999). In any case, Treg cells appear to play the key role in our experiments, something suggested not only by the Treg-depletion experiment, but also by the marked increase in the frequency of Foxp $3^{+} \mathrm{T}$ cells in anti-CD4 treated mice. In addition we found that Treg depletion in advance of anti-CD4 treatment did not have a major impact on tolerance induction. On the contrary, $\mathrm{CD} 25$ depletion after anti-CD4 treatment abrogated tolerance induction. Although these data are not conclusive, as we cannot follow the fate of antigen-specific cells, they suggest that induced Treg cells are probably key participants in tolerance induction. Such tolerance mechanism is also distinct 


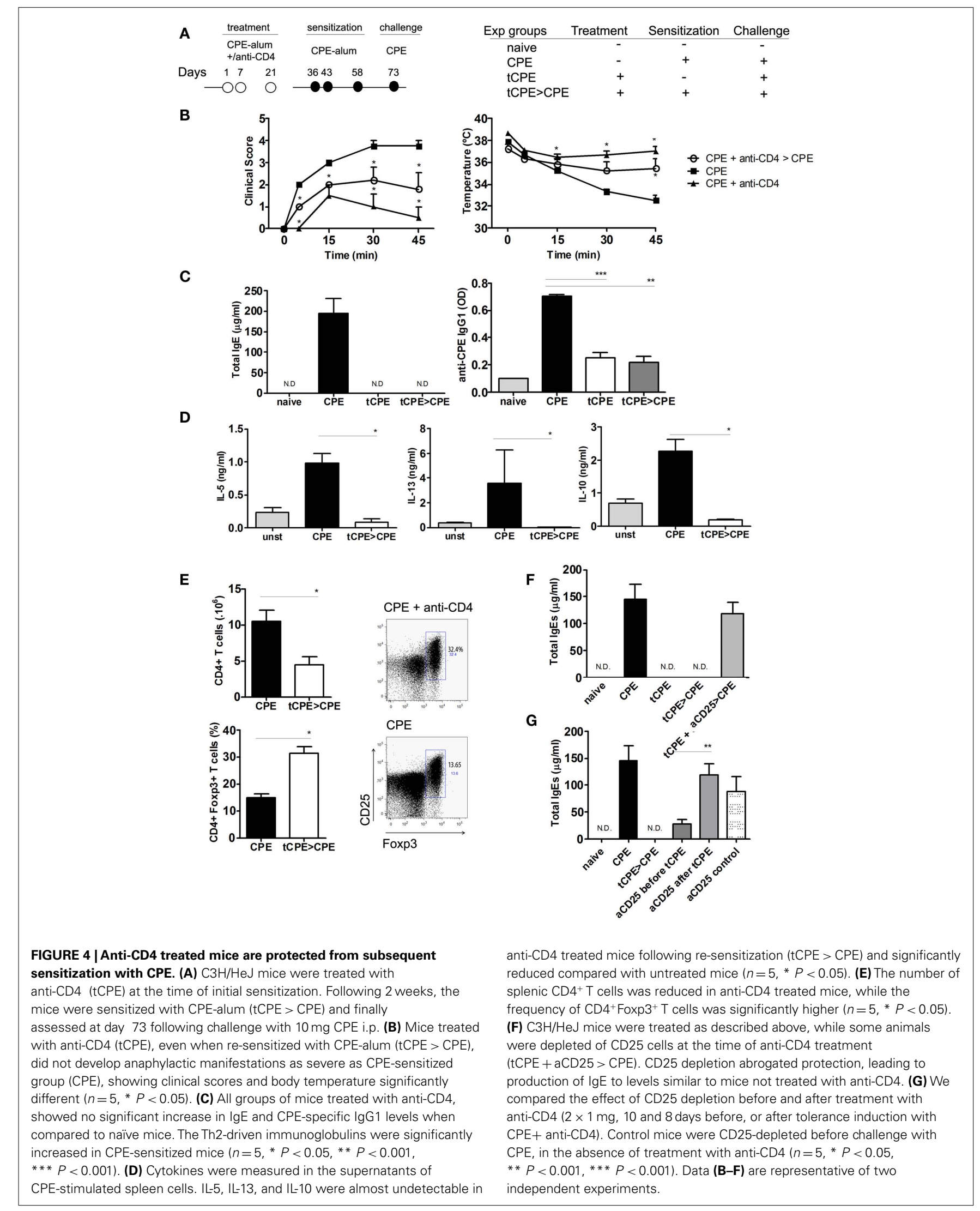



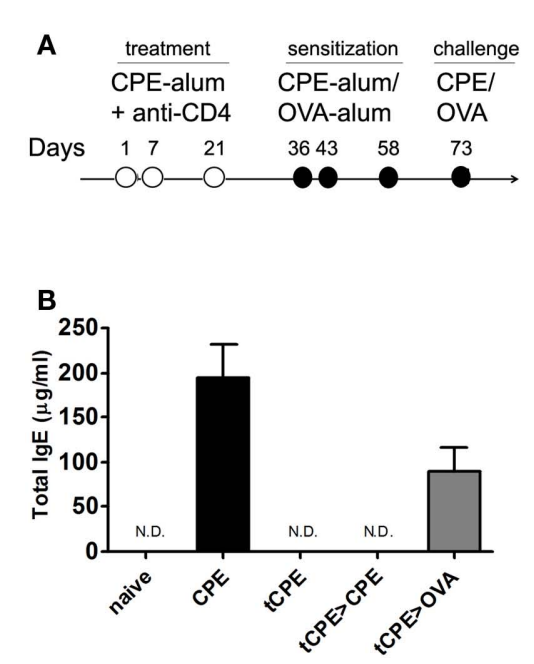

FIGURE 5 | Anti-CD4 treatment induces antigen-specific tolerance. (A) $\mathrm{C} 3 \mathrm{H} / \mathrm{HeJ}$ mice were sensitized with CPE or OVA, and treated with anti-CD4 as described. The animals were assessed at day 73. (B) Mice treated with anti-CD4 mAb (tCPE) even following subsequent sensitization with the same antigens (tCPE $>C P E$ ) maintained IgE titers significantly lower than control animals $\left(C P E ;{ }^{*} P<0.05\right)$. However, anti-CD4 treatment did not prevent the production of IgE following subsequent sensitization with OVA, a different

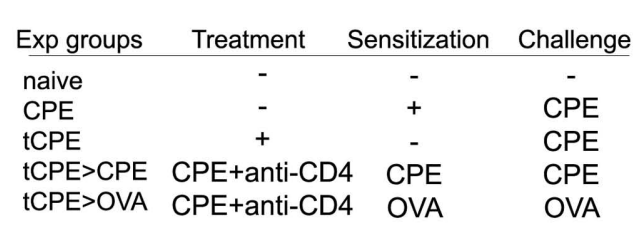

C

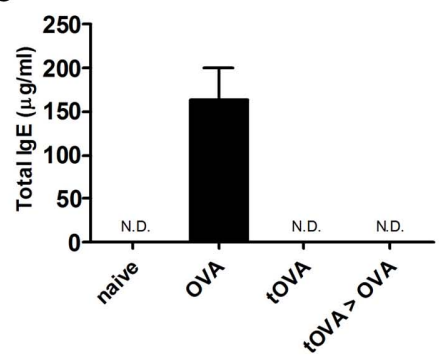

antigen (tCPE > OVA), that led to IgE titers similar to the levels of control mice (CPE). (C) Equivalent experiment to (B) where OVA was used as the antigen to sensitize $\mathrm{C} 3 \mathrm{H} / \mathrm{HeJ}$ mice. OVA sensitization led to high titers of IgE (OVA). Exposure to OVA in presence of CD4-blockade (tOVA) prevented IgE production even following subsequent sensitization with OVA (tOVA > OVA) $\left(n=5,{ }^{*} P<0.05\right)$. Data $(\mathbf{B}, \mathbf{C})$ are representative of two independent experiments. from other immune tolerance induction protocols that rely on the production of IL-10 or shifting the response toward Th1 (Ebner et al., 1997; Francis et al., 2003; Akdis et al., 2004; Valenta et al., 2004).

When we treated with anti-CD4 mAb mice previously sensitized with CPE, we could not prevent manifestations of anaphylaxis given the presence of high IgE titers. It remains, however, to be shown whether therapeutic neutralization of IgE, could allow tolerance to be imposed in a way preventing further production of IgE. In fact, our results with a mouse model of allergic airways disease show that tolerance can be achieved in pre-sensitized mice, even following one episode of airways inflammation (Agua-Doce and Graca, 2011). Taken together, these findings suggest IgE is not preventing tolerance from being achieved within the $\mathrm{T}$ cell compartment, but high levels of IgE are sufficient to lead to acute manifestations of disease. In addition, memory cells have been recognized as a major barrier for therapeutic induction of tolerance (Adams et al., 2003). In any case, immune tolerance can be induced in some experimental models with anti-CD4, in presence of memory T cells (Agua-Doce and Graca, 2011). Concerning tolerance induction to CPE, we cannot conclude whether, besides high IgE levels, the presence of memory $\mathrm{T}$ cells in pre-sensitized mice constitute a barrier to tolerance induction.

Interestingly, we found sensitized mice only developed mild manifestations of anaphylaxis when injected with CPE-alum, while CPE alone triggered a severe anaphylactic response with a sharp drop in core body temperature. However, when we injected alum alone, or alum together with a different antigen (OVA), we could not observe a protective effect toward subsequent sensitization with CPE.

To find an efficient and specific therapy for peanut-induced anaphylaxis has been a major challenge (Burks et al., 2008). Once the diagnosis is established, the course of action is restricted to strict elimination of the causative allergen from the patient's diet, and it was estimated that about $50 \%$ of the affected individuals develop an accidental reaction over a 2 -year period (Sicherer et al., 2003). Distinct approaches to induce tolerance to food allergens have been or are being pursued (Canonica and Passalacqua, 2003; Clark et al., 2009; Jones et al., 2009; Blumchen et al., 2010; Vickery et al., 2011). It is however yet unclear whether the evidence will support clinical adoption of any of those tolerogenic strategies.

We believe our data provide evidence that targeting CD4 T cells may provide a way to achieve or facilitate tolerance induction to systemic antigens, such as the ones that may trigger anaphylaxis.

\section{ACKNOWLEDGMENTS}

We are grateful to A. Wesley Burks (Duke University) for helpful advice and for providing samples of CPE to validate the CPE we have produced in-house. We thank Herman Waldmann (University of Oxford) for hybridomas of anti-CD4 and antiCD25. Funded by Fundacao para a Ciencia e Tecnologia PortugalPTDC/SAU-MII/64279/2006. The authors have no competing financial interests.

\section{REFERENCES}

Adams, A. B., Pearson, T. C., and Larsen, C. P. (2003). Heterologous immunity: an overlooked barrier to tolerance. Immunol. Rev. 196, 147-160.
Agua-Doce, A., and Graca, L. (2011). Prevention of house dust mite induced allergic airways disease in mice through immune tolerance. PLoS ONE 6, e22320. doi:10.1371/journal.pone.0022320 
Akdis, C. A., Blesken, T., Akdis, M., Wuthrich, B., and Blaser, K. (1998). Role of interleukin 10 in specific immunotherapy. J. Clin. Invest. 102, 98-106.

Akdis, M., Verhagen, J., Taylor, A., Karamloo, F., Karagiannidis, C., Crameri, R., Thunberg, S., Deniz, G., Valenta, R., Fiebig, H., Kegel, C., Disch, R., Schmidt-Weber, C. B., Blaser, K., and Akdis, C. A. (2004). Immune responses in healthy and allergic individuals are characterized by a fine balance between allergenspecific T regulatory 1 and $\mathrm{T}$ helper 2 cells. J. Exp. Med. 199, 1567-1575.

Berin, M. C., Zheng, Y., Domaradzki, M., Li, X. M., and Sampson, H. A. (2006). Role of TLR4 in allergic sensitization to food proteins in mice. Allergy 61, 64-71.

Blumchen, K., Ulbricht, H., Staden, U., Dobberstein, K., Beschorner, J., De Oliveira, L. C., Shreffler, W. G., Sampson, H. A., Niggemann, B., Wahn, U., and Beyer, K. (2010). Oral peanut immunotherapy in children with peanut anaphylaxis. J. Allergy Clin. Immunol. 126, 83-91 e81.

Burks, A. W., Laubach, S., and Jones, S. M. (2008). Oral tolerance, food allergy, and immunotherapy: implications for future treatment. J. Allergy Clin. Immunol. 121, 1344-1350.

Canonica, G. W., and Passalacqua, G. (2003). Noninjection routes for immunotherapy. J. Allergy Clin. Immunol. 111, 437-448; quiz 449.

Clark, A. T., Islam, S., King, Y., Deighton, J., Anagnostou, K., and Ewan, P. W. (2009). Successful oral tolerance induction in severe peanut allergy. Allergy 64, 1218-1220.

Cobbold, S. P., Adams, E., Graca, L., Daley, S., Yates, S., Paterson, A., Robertson, N. J., Nolan, K. F., Fairchild, P. J., and Waldmann, H. (2006). Immune privilege induced by regulatory $\mathrm{T}$ cells in transplantation tolerance. Immunol. Rev. 213, 239-255.

Cobbold, S. P., Castejon, R., Adams, E., Zelenika, D., Graca, L., Humm, S., and Waldmann, H. (2004). Induction of foxP3 + regulatory $\mathrm{T}$ cells in the periphery of $\mathrm{T}$ cell receptor transgenic mice tolerized to transplants. J. Immunol. 172, 6003-6010.

Duarte, J., Agua-Doce, A., Oliveira, V. G., Fonseca, J. E., and Graca, L. (2010). Modulation of IL-17 and Foxp3 expression in the prevention of autoimmune arthritis in mice. PLoS ONE 5, e10558. doi:10.1371/journal.pone. 0010558

Ebner, C., Siemann, U., Bohle, B., Willheim, M., Wiedermann, U., Schenk, S., Klotz, F., Ebner, H., Kraft, D., and Scheiner, O. (1997).
Immunological changes during specific immunotherapy of grass pollen allergy: reduced lymphoproliferative responses to allergen and shift from TH2 to TH1 in T-cell clones specific for $\mathrm{Phl} \mathrm{p} \mathrm{1,} \mathrm{a} \mathrm{major} \mathrm{grass}$ pollen allergen. Clin. Exp. Allergy 27, 1007-1015.

Francis, J. N., Till, S. J., and Durham, S. R. (2003). Induction of IL$10+\mathrm{CD} 4+\mathrm{CD} 25+\mathrm{T}$ cells by grass pollen immunotherapy. J. Allergy Clin. Immunol. 111, 1255-1261.

Graca, L., Chen, T. C., Le Moine, A., Cobbold, S. P., Howie, D., and Waldmann, H. (2005). Dominant tolerance: activation thresholds for peripheral generation of regulatory $\mathrm{T}$ cells. Trends Immunol. 26, 130-135.

Graca, L., Honey, K., Adams, E., Cobbold, S. P., and Waldmann, $\mathrm{H}$. (2000). Cutting edge: anti-CD154 therapeutic antibodies induce infectious transplantation tolerance. $J$. Immunol. 165, 4783-4786.

Graca, L., Le Moine, A., Cobbold, S. P., and Waldmann, H. (2003). Antibody-induced transplantation tolerance: the role of dominant regulation. Immunol. Res. 28, 181-191.

Graca, L., Le Moine, A., Lin, C. Y., Fairchild, P. J., Cobbold, S. P., and Waldmann, H. (2004). Donor-specific transplantation tolerance: the paradoxical behavior of CD4+CD25+ T cells. Proc. Natl. Acad. Sci. U.S.A. 101, 10122-10126.

Graca, L., Thompson, S., Lin, C. Y., Adams, E., Cobbold, S. P., and Waldmann, H. (2002). Both CD4(+)CD25(+) and CD4(+)CD25(-) regulatory cells mediate dominant transplantation tolerance. J. Immunol. 168, 5558-5565.

Jones, S. M., Pons, L., Roberts, J. L., Scurlock, A. M., Perry, T. T., Kulis, M., Shreffler, W. G., Steele, P., Henry, K. A., Adair, M., Francis, J. M., Durham, S., Vickery, B. P., Zhong, X., and Burks, A. W. (2009). Clinical efficacy and immune regulation with peanut oral immunotherapy. $J$. Allergy Clin. Immunol. 124, 292-300, 300 e291-297.

Kanny, G., Moneret-Vautrin, D. A., Flabbee, J., Beaudouin, E., Morisset, M., and Thevenin, F. (2001). Population study of food allergy in France. J. Allergy Clin. Immunol. 108, 133-140.

Kendal, A. R., and Waldmann, $\mathrm{H}$ (2010). Infectious tolerance: therapeutic potential. Curr. Opin. Immunol. 22, 560-565.

Kon, O. M., Sihra, B. S., Compton, C. H., Leonard, T. B., Kay, A. B., and Barnes, N. C. (1998). Randomised, doseranging, placebo-controlled study of chimeric antibody to CD4 (keliximab) in chronic severe asthma. Lancet 352, 1109-1113.

Li, L., Crowley, M., Nguyen, A., and Lo, D. (1999a). Ability of a nondepleting anti-CD4 antibody to inhibit Th2 responses and allergic lung inflammation is independent of coreceptor function. J. Immunol. 163 6557-6566.

Li, Y., Li, X. C., Zheng, X. X., Wells, A. D., Turka, L. A., and Strom, T. B. (1999b). Blocking both signal 1 and signal 2 of T-cell activation prevents apoptosis of alloreactive T cells and induction of peripheral allograft tolerance. Nat. Med. 5 , 1298-1302.

Li, X. M., Serebrisky, D., Lee, S. Y. Huang, C. K., Bardina, L., Schofield, B. H., Stanley, J. S., Burks, A. W. Bannon, G. A., and Sampson, H. A. (2000). A murine model of peanut anaphylaxis: $\mathrm{T}$ - and B-cell responses to a major peanut allergen mimic human responses. J. Allergy Clin. Immunol. 106, 150-158.

Lin, C. Y., Graca, L., Cobbold, S. P., and Waldmann, H. (2002). Dominant transplantation tolerance impairs CD8+ T cell function but not expansion. Nat. Immunol. 3, 1208-1213.

Morafo, V., Srivastava, K., Huang, C. K., Kleiner, G., Lee, S. Y., Sampson, H. A., and Li, A. M. (2003) Genetic susceptibility to food allergy is linked to differential TH2-TH1 responses in $\mathrm{C} 3 \mathrm{H} / \mathrm{HeJ}$ and $\mathrm{BALB} / \mathrm{c}$ mice. J. Allergy Clin. Immunol. 111, 1122-1128.

Oliveira, V. G., Caridade, M., Paiva, R. S., Demengeot, J., and Graca, L. (2011). Sub-optimal CD4(+) T-cell activation triggers autonomous TGF-betadependent conversion to Foxp3(+) regulatory T cells. Eur. J. Immunol. 41, 1249-1255.

Pons, L., Ponnappan, U., Hall, R. A., Simpson, P., Cockrell, G., West, C. M., Sampson, H. A., Helm, R. M., and Burks, A. W. (2004). Soy immunotherapy for peanut-allergic mice: modulation of the peanutallergic response. J. Allergy Clin. Immunol. 114, 915-921.

Qin, S., Cobbold, S. P., Pope, H., Elliott, J., Kioussis, D., Davies, J., and Waldmann, H. (1993). "Infectious" transplantation tolerance. Science 259 974-977.

Salooja, N., Kemball-Cook, G., Tuddenham, E. G., and Dyson, J. (2002). Use of a non-depleting anti-CD4 antibody to modulate the immune response to coagulation factors VIII and IX. Br. J. Haematol. 118, 839-842.

Sampson, H. A. (2004). Update on food allergy. J. Allergy Clin. Immunol. 113 , 805-819; quiz 820.
Sicherer, S. H., Munoz-Furlong, A., and Sampson, H. A. (2003). Prevalence of peanut and tree nut allergy in the United States determined by means of a random digit dial telephone survey: a 5-year follow-up study. J. Allergy Clin. Immunol. 112, 1203-1207.

Valenta, R., Ball, T., Focke, M., Linhart, B., Mothes, N., Niederberger, V., Spitzauer, S., Swoboda, I., Vrtala, S., Westritschnig, K., and Kraft, D. (2004). Immunotherapy of allergic disease. Adv. Immunol. 82, 105-153.

Vickery, B. P., Scurlock, A. M., Jones, S. M., and Burks, A. W. (2011). Mechanisms of immune tolerance relevant to food allergy. J. Allergy Clin. Immunol. 127, 576-584; quiz 585-576.

Waldmann, H., Adams, E., Fairchild, P., and Cobbold, S. (2006). Infectious tolerance and the long-term acceptance of transplanted tissue. Immunol. Rev. 212, 301-313.

Waldmann, H., and Cobbold, S. (2001). Regulating the immune response to transplants. a role for CD4+ regulatory cells? Immunity 14 , 399-406.

Wells, A. D., Li, X. C., Li, Y., Walsh, M. C., Zheng, X. X., Wu, Z., Nunez, G., Tang, A., Sayegh, M., Hancock, W. W., Strom, T. B., and Turka, L. A. (1999). Requirement for T-cell apoptosis in the induction of peripheral transplantation tolerance. Nat. Med. 5, 1303-1307.

Conflict of Interest Statement: The authors declare that the research was conducted in the absence of any commercial or financial relationships that could be construed as a potential conflict of interest.

Received: 24 June 2011; paper pending published: 12 July 2011; accepted: 04 October 2011; published online: 19 October 2011.

Citation: Duarte J, Caridade $M$ and Graca L (2011) CD4-blockade can induce protection from peanut-induced anaphylaxis. Front. Immun. 2:56. doi: 10.3389/fimmu.2011.00056

This article was submitted to Frontiers in Immunological Tolerance, a specialty of Frontiers in Immunology.

Copyright (C) 2011 Duarte, Caridade and Graca. This is an open-access article subject to a non-exclusive license between the authors and Frontiers Media $S A$, which permits use, distribution and reproduction in other forums, provided the original authors and source are credited and other Frontiers conditions are complied with. 


\section{APPENDIX}

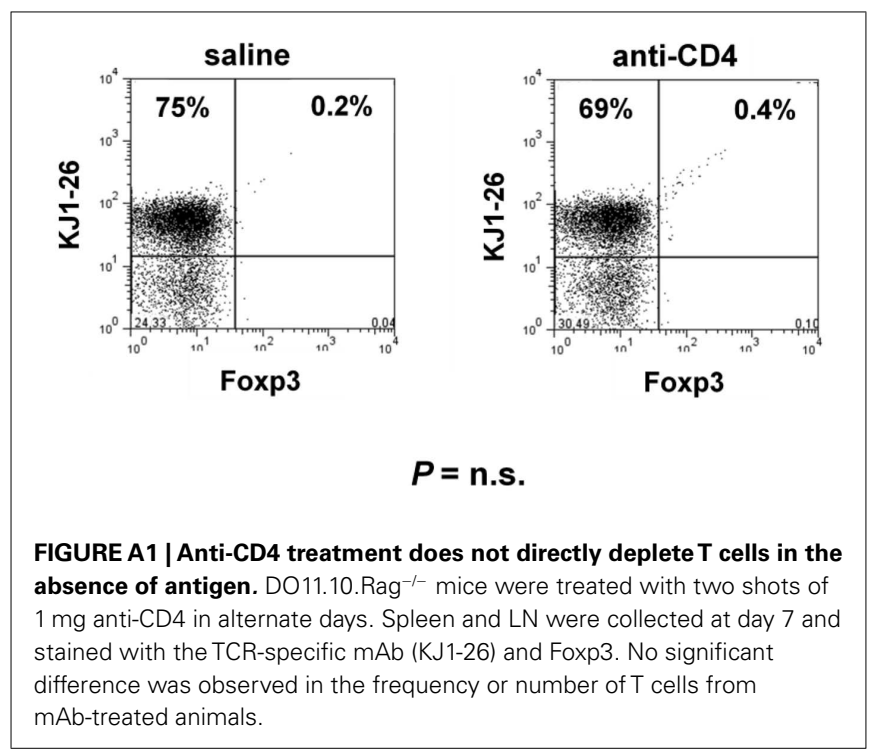

